International Association for the Psychology of Language Learning (IAPLL)

Journal for the Psychology of Language Learning

ISSN: 2642-7001. http://www.iapll.com/journal

Issue 1, June 2019, pp. 6-26.

\title{
George Herbert Mead and the Psychology of Language Learning
}

\author{
Phil Benson, Macquarie University, Sydney, Australia
}

\begin{abstract}
George Herbert Mead was an early-twentieth century American psychologist, who work on social psychology has been especially influential in sociology. Although Mead wrote a good deal on language, his work has had much less influence on linguistics and applied linguistics.

Outlining key ideas from Mead's work on the emergence of language and mind from social interaction in the environment, this paper makes a case for Mead to be considered among the foundational figures in the psychology of language learning. It argues that his work is especially worth reading as a source of ideas that might underpin an ecological view of the psychology of language learning.
\end{abstract}

Keywords: George Herbert Mead, ecology of language learning, environment, behaviourism, language and mind

The terms 'ecology' and 'environment' have an interesting history in applied linguistics. They were introduced in Kramsch's (2002) collection, entitled Language acquisition and language socialization: Ecological perspectives, but Leather (2002), Lemke (2002) and van Lier (2002) were the only contributors to the volume to explicitly adopt an ecological perspective. The closest that we have to a fully developed ecological perspective is van Lier's (2004) pioneering book, The ecology and semiotics of language learning: A sociocultural perspective. Van Lier's main ecological sources were the psychologists James Gibson and Uri Bronfenbrenner (Bronfenbrenner, 1979; Gibson, 1979), but as the title of the book suggests, the approach is only partly ecological. Charles Peirce's (1992/1998) semiotics and Lev Vygotsky's (1978, 1986) psychology of learning bear much of the theoretical burden. Kramsch (2008) later published an article in Language Teaching, which again turned out to be only partly ecological in 
its aim of outlining "an ecological perspective on foreign language education, based on complexity theory" (Kramsch, 2008, p. 389). Tudor (2003, p. 4) provides one of the best definitions of the ecological perspective as one that "involves exploring language teaching and learning within the totality of the lives of the various participants involved", while Kramsch (2002: p. 8) describes it as a perspective that "strives to encompass the totality of the relationships that a learner, as a living organism, entertains with all aspects of his/her environment".

One of the problems with the ecological approach to date, however, is that the concept of 'the environment' is insufficiently specified in its relation to language and language learning, and in many accounts it is insufficiently separated from social context. We are yet to develop an ecological approach to the psychology of language learning theory in which the environment plays the central role. Gibson and Bronfenbrenner remain the 'go-to' sources for an ecological perspective, but neither offers an ecological account of language and environment. This paper discusses the pioneering work of the early-twentieth century psychologist George Herbert Mead (1863-1934) on the emergence of language and mind from social interaction in the environment. Mead's work is widely referenced in sociology, but it has had little impact on applied linguistics, (but see Mercer, 2016, who cites Mead as a source on the social construction of the self). Although Mead does not present a fully formed ecological view of language and language learning, I want to argue that his work deserves attention as a potential foundational source for the psychology of language learning.

\section{George Herbert Mead}

Mead was an American philosopher who worked within the pragmatist tradition of philosophy, alongside John Dewey, a close friend and colleague at the Universities of Michigan and Chicago. Trained as a philosopher, Mead was something of a polymath. He studied with the German psychologist Wilhelm Wundt and worked in sociology at the University of Chicago. One of his main philosophical interests was in the nature of psychology as a field of inquiry. Mead is now best known for a book published posthumously under the title Mind, self, and society from the standpoint of a social behaviorist (MSS) (Mead, 1934), which was compiled from “a collage of stenographers' and students' notes and unpublished manuscripts" by its editor Charles W. Morris (Huebner, 2012, p. 134). Mead scholars question how far MSS truly reflects 
Mead's thinking and, in particular, they question Morris's presentation of him as a social behaviourist. Da Silva and Vieira (2011, p. 363) observe that it was Morris, rather than Mead, who used this term, although Mead did, in fact, describe his psychology as behaviouristic in at least two papers (Mead, 1922, 1924-5). Although MSS is the main source for this paper, its view of language is corroborated by a number of articles that Mead published over the course of his career (Mead, 1904, 1910, 1922, 1925).

For sociologists, Mead is the founding father of symbolic interactionism (Blumer, 1966, 1980), although he did not use this term himself. Jürgen Habermas's work on the theory of communicative action also references MSS (Habermas, 1981). More recently, Mead's ideas have been taken up as a philosophical foundation for work in neuroscience (Madzia, 2013) and neurosociology (Franks, 2013; Shook, 2013). Despite the fact that language was central to his view of human psychology, Mead has had very little influence on the psychology of language learning. This could be because late $20^{\text {th }}$-century second language acquisition theory was founded on Chomsky's critique of behaviourism (Chomsky, 1959). The psychology of language learning has moved on from Chomsky's 'mentalism' to a broadly social view that places social interaction at the heart of the psychological processes in language acquisition, but applied linguists might be forgiven for assuming that there is little to be learned from a book whose title explicitly declares its author's behaviourist standpoint. However, Mead's view of language and mind differed radically from Skinner's view of language as conditioned reflex that Chomsky's critique targeted (Skinner, 1957). Indeed, Mead's behaviourism is much more closely allied to contemporary social perspectives on language and language learning, especially in its insistence that all mental phenomena, and language especially, are fundamentally social in origin. Critics of Skinner and Chomsky alike would certainly agree with Mead's observation that human nature is "social through and through, and always presupposes the truly social individual" (Mead, 1934, p. 229).

\section{Mead's Social Behaviorism}

Mead published a paper entitled "A behavioristic account of the significant symbol" (Mead, 1922), and in a later paper he referred to a "behavioristic psychology" that had "shifted its interest from psychical states to external conduct” (Mead, 1925, p. 251). The term that Mead appears not to have used was 'social behaviorism', which Morris introduced in order to 
distinguish Mead's approach from that of John B. Watson (1914), who is considered to be one of the founders of behaviouristic psychology (Morris, 1934, p. xvi). In what sense, then, was Mead a behaviourist?

As a philosopher, Mead was interested in the big questions of psychology and, in particular, with the nature of the objects of psychological inquiry. He was not an experimental psychologist and he only occasionally drew on experimental evidence to support his positions. Mead's argument relies largely on a speculative model of the evolution of human society that lines up gesture, language, consciousness, and other psychological phenomena in an evolutionary sequence that is supported more by an 'it could not have happened otherwise' logic than it is by historical evidence. The argument is behaviouristic mainly in the sense that it begins from the use of gesture in social activity. Social psychology is not behaviouristic, Mead argued, "in the sense of ignoring the inner experience of the individual", but "in the sense of starting off with an observable activity - dynamic, ongoing social process, and the social acts which are its component elements" (Mead, 1934, p. 7).

Although Mead may not have described himself as a 'social' behaviourist, the idea that behaviour is social was central to his view of language and psychology. The entire process of evolution from gesture to higher mental phenomena is motivated by "the complex life of the group", in which "the acts of the individuals are completed only through the acts of other individuals" (Mead, 1925, p. 262). Mead did not describe his approach as 'ecological', but the idea of interaction with the environment was fundamental to his view of behaviour. Mead often used the word 'conduct' in place of 'behaviour'. "Conduct", he wrote, "is the sum of the reactions of living beings to their environments, especially to the objects which their relation to the environment has "cut out of it" (Mead, 1922, p. 160). Among these objects, "social objects", or "other living forms which belong to the same group" have a peculiar importance (Mead, 1922, p. 160) For human beings, these social objects are other human beings, and it is from the preexistence of other human beings in the environment of the individual that Mead's behaviourist account of language and mind begins.

I will come back to Mead's view of the environment later in this paper. First, I will attempt to summarise the essential steps in his argument on the emergence of language and mind, which might underpin and environmental view of the psychology of language learning. The argument begins with gesture. 


\section{Gesture}

Mead was a behaviourist for another reason. His goal was to explain how mental phenomena could emerge from a world in which there were no mental phenomena. All species react to their environments, so human psychology must, in some way, have evolved from these reactions: that is, from conduct or behaviour. And as the behaviour of those species that are closest to humans is social, human psychology must have evolved from social behaviour: that is, from gestural behaviour toward social objects, i.e., other humans, in the environment. Mead accepted Wundt's assumption that language originated in gesture. He also praised Charles Darwin's The expression of the emotions in man and animals Darwin, 1872), which he described as 'one of the important documents for the psychology of language' (Mead, 1934, p. 15). Darwin's insight was to identify a series of acts or 'beginnings of acts' that expressed emotions. The snarl of a dog, for example, was both the beginning of an act of aggression and an expression of the dog's anger (Mead, 1934, p. 16). But Mead objected to the idea that these acts were undertaken in order to express emotions, because this presupposed that there was already some content in the mind of the animal to be expressed. The same objection was made to the linguists of the time who 'assume that language existed for the purpose of conveying certain ideas, certain feelings' (Mead, 1934, p. 16). The gestures of animals and human speech were not to be explained by the meanings they expressed. On the contrary, the problem was to explain how the expression of meaning could emerge from gesture and speech.

Mead's concept of gesture implies three evolutionary steps. Gestures are, first, 'attitudes', a term that Mead reserves for the movements involved in the early stages of the act. Second, when a gesture communicates an intention to another, it becomes a 'symbol'. Third, the gesture becomes a 'significant symbol' when it calls out the response of the other in the mind of the one who has made the gesture. The evolutionary journey from gesture to speech is completed via the vocal gesture, which becomes the vehicle par excellence for the significant symbol.

Taking these steps one a time, 'attitudes' begin an act by putting the organism in a state of readiness for the completion of the act. Mead illustrates this with the example of grasping a hammer.

If one is approaching a hammer he is muscularly all ready to seize the handle of the hammer. The later stages of the act are present in the early stages - not simply in the 
sense that they are all ready to go off, but in the sense that they serve to control the process itself. They determine how we are going to approach the object, and the steps in our early manipulation of it. (Mead, 1934, p. 11)

The complete act is present in the gestures that initiate the act, and these gestures predict the act as a whole.

The second step involves the part that gestures play in the social process. For Mead, gesture is the 'basic mechanism' of the social process. Its function is to "make adjustments possible among the individuals implicated in any given social act with reference to the object or objects with which that act is concerned" (Mead, 1934, p. 46). Mead's example of the conversation of gestures is that of the dog-fight in which each dog adjusts its attitudes to the other dog's attitudes until one dog backs down (Mead, 1934, pp. 42-3). When animals respond to each other's attitudes in this way, their gestures serve as symbols for the later stages of acts that are not completed. They are symbols that stand for intentions, in the sense that they are parts of acts that are already begun. But they are not as yet significant symbols.

The significant symbol is the third step. In the dog-fight, the attitude of first dog reveals that it is about to attack; the response of the second dog is an attitude that curtails the attack of the first dog, and so on until the fight reaches its conclusion. But neither animal 'means' these attitudes in the sense that there is some idea behind them. However, when a person shakes their fist in another person's face, the other will assume that there is some idea behind the gesture. The other person knows that the fist-shaker does not intend to strike him; he only has the idea of doing so or, perhaps, the more general idea of anger. The fist-shaking stands for the complete act of striking. The gesture means the idea that the individual has, and when the 'gesture means this idea behind it and it arouses that idea in the other individual, then we have a significant symbol' (Mead, 1934, p. 45). In the dog fight, each gesture calls out an appropriate response. In the shaking of the fist, "we have a symbol which answers to a meaning in the experience of the first individual and which also calls out that meaning in the second individual" (Mead, 1934, pp. 4546). In that situation, the gesture becomes what we call 'language', the exchange of significant symbols.

But how do we get from a gesture that simply stands as a symbol for a complete act to a gesture that stands for the idea of that act, in the sense that it answers to a meaning in the 
experience of the person who makes it? The crucial step, here, is that of 'taking the attitude of the other', a step that is difficult to grasp, because Mead offers no explanatory mechanism for it. (For a potential explanation involving 'mirror neurons', which are activated both when a person performs an action and also a person when observe the same action performed by another, see Madzia, 2013; Iacobini, 2008). For Mead, the meaning of a person's gesture appears in his own experience "in so far as he takes the attitude of the second individual toward that gesture".

Gestures become significant symbols "when they implicitly arouse in an individual making them the same responses which they explicitly arouse, or are supposed to arouse, in other individuals, the individuals to whom they are addressed" (Mead, 1934, p. 47). However it occurs, this mutual taking of the attitude of the other toward one's own gestures is the starting point for the "conscious or significant conversation of gestures" (Mead, 1934, p. 46), in which the gesture is a symbol of the idea of the act, rather than a symbol of the act itself.

\section{The Vocal Gesture}

The journey from gesture to language passes through the vocal gesture, which has the crucial characteristic of being "one of those social stimuli which affect the form that makes it in the same fashion that it affects the form when made by another" (Mead, 1934, p. 62). We cannot see our own facial expressions. When we hear ourselves speak, we hear what others hear and we also pay attention. From the perspective of taking the attitude of the other toward one's own gestures, therefore, the vocal gesture has the important characteristic that it "arouses in the individual who makes it a tendency to the same response that it arouses in another" (Mead, 1925, p. 271). As the response of the hearer enters into the experience of the speaker, the speaker "will find himself tending to act toward himself as the other acts toward him" (Mead, 1925, p. 271). And it is through this tendency to act as others act towards ourselves that we understand what others do and say. The same tendency explains how we come to associate specific vocal gestures with specific ideas. A person who pronounces, and hears himself pronounce, the word 'table' "has aroused in himself the organized attitudes of his response to an object, in the same fashion as that in which he has aroused it in another" (Mead, 1925, p. 272). This 'aroused organized attitude' is what we call the idea of a table; "the ideas of what we are saying accompany all of our significant speech" (Mead, 1925, p. 272). 
Mead took the idea that speech evolved from vocal gesture, or animal cry, from Wundt. It was not an especially new idea among those who sought a physiological account of the origin of language. However, Mead's account of the emergence of language as a symbolic system from the conversation of gestures that regulates the social process in all species was a radically new departure. The idea that human intelligence had developed "through the process of the symbolization of experience which gestures - especially vocal gestures - have made possible" was also new. This specialization within the field of gesture, he argued, was ultimately responsible for "the origin and growth of present human society and knowledge, with all the control over nature and over the human environment which science makes possible" (Mead, 1934, 13-14 footnote).

\section{Language}

In the context of its times, the most radical aspect of Mead's view of language was its reversal of the assumption that the function of language was to express thought. Mead was one of several thinkers who were developing this view in the early decades of the twentieth century, including his colleague John Dewey, the philosopher Grace de Laguna, and the anthropologist Bronislaw Malinowski (de Laguna, 1970; Dewey, 1925; Malinowski, 1923). There are also parallels with Vygostsky's $(1978,1986)$ and Volosinov's (1973) views on language and thought. (De Laguna (1970: 15-18) produced an impressive list of quotations from writers such as Henry Sweet, W. D. Whitney, Herman Paul, Bertrand Russell and Edward Sapir to show that the dominant view was, indeed, that language functioned to express or communicate thought. On this point, Mead's position was clear: "Out of language emerges the field of mind" (Mead, 1934, p. 133). Comments of this kind, which are scattered throughout $M S S$, illustrate an explanatory procedure to which Mead was firmly attached. Once a phenomenon had been placed in its evolutionary order, under no circumstance could later phenomena enter into its the explanation of its origins. Language could not exist for the purpose of expressing or communicating thought, because language preceded thought. Language was to be approached, therefore, within the strictly limited frame of its evolutionary predecessors, "not from the standpoint of inner meanings to be expressed, but in its larger context of co-operation in the group taking place by means of signals and gestures" (Mead, 1934, p. 6). It must be seen as emerging, not from 
thought, but "from the point of view of the gestural type of conduct within which it existed without being as such a definite language" (Mead, 1934, pp. 16-17).

Mead had a good deal to say about language, especially in an early paper on the relations of psychology and philology, in which he attempted to capture the study of language for psychology (Mead, 1904). He had little to say about the evolution of language structures and forms, which is the favoured topic of the study of language evolution today (e.g., Tallerman \& Gibson, 2012). In fact, Mead seems to have viewed the comparative study of languages as something of a distraction from the treatment of language itself as an object of psychology. "Speech is an act," he wrote, "and like any other act has its natural history which psychology can give us from a study of its nature and its analogy to other acts" (Mead, 1904, p. 383). From a modern perspective, his ideas on the higher forms of language have three points of interest. The first concerns the relation of the individual to the language(s) they speak. The second relates to the nature of language forms, or in Mead's terms, the significant symbol, and the third concerns the embodiment of meaning.

Like many writers before and since, Mead failed to make a clear distinction between language and speech, partly because language was speech in its earliest evolutionary form. In its higher forms, however, language is described as "a set of symbols answering to certain content which is measurably identical in the experience of the different individuals" (Mead, 1934, p. 54). This 'set' of shared symbols could be thought of as the language of a group of individuals who interact with each other. (Clearly, there is not simply one language, but Mead does not deal explicitly with the distinction between language in general and languages in particular. In Mead's later work, the mechanism for the emergence of this set of symbols is again the taking of the attitude of others within a social group. In Mead (1904), this question is dealt with in a different way, through Wundt's idea of the Volkseele, or 'community mind'. Mead first observes that language, alongside myth and custom, has two characteristics that distinguish it from the phenomena of individual consciousness. It is independent of the duration of the individual's life and it evolves from generation to generation. In view of these characteristics, Mead postulates that language is a phenomenon of an "empirical community-mind within which such processes take place whose boundaries are not those of the individuals who make up the group, but those of the community" (Mead, 1904, p. 376). From this point of view, language is also an 'objective fact' with 'objective laws'. Although individual minds are the mechanisms of language growth 
and change, the product lies outside the experience of the minds that are responsible for it. Language, custom and law, he writes, "are so vast and overwhelming in their force and mass that they receive the individual only as the ocean receives the drop of water, though the ocean is nothing but drops of water" (Mead, 1904, p. 378).

This view of the objectivity of language aligns Mead with Saussure (1983), who is most closely associated with this view, although it is Wundt, not Saussure, who is acknowledged as its source. Yet, it is also a problematic view, because it places the 'community-mind' before the emergence of language. It presupposes a community that shares a language, without accounting for the role of language in the emergence of the community. In MSS, this problem is tackled more satisfactorily through an extension of the mechanism of taking the attitude of the other, to a 'generalized other'. In this respect, Mead's approach had always differed radically from Saussure's in its rejection of any notion of the arbitrariness of the significant symbol. Mead found this notion, not in Saussure, but in what he called 'associational psychology', in which "language is almost unavoidably seen as an invention" (Mead, 1904. p. 379). This view, he argued, is more suited to "a Volapük" (a nineteenth-century invented language) than a natural language, in which symbols and their meanings are rooted in the social process.

The starting point of Mead's treatment of language forms as significant symbols is the function of the vocal gesture in communication. If there is to be communication, symbols, or language forms, must mean more or less the same thing to the individuals involved. This is, in effect, a condition of the significance of particular vocal gestures. As we have seen, the mechanism for the emergence of the significant symbol is taking the attitude of the other. The vocal gesture becomes language when it arouses the same response in the speaker that it arouses in the hearer. A dog is not alarmed by its own bark, but a speaker who hears himself say the word 'dog' has more or less the same response to what he hears as another person does. We could say that the word 'dog' now stands for the idea of a dog, as long as we remember that this idea is no more than a shared response to the word.

The emergence of language presupposes a generalization of this basic process. As Mead puts it, through the use of vocal gestures, we are "continually arousing in ourselves those responses which we call out in other persons, so that we are taking the attitudes of the other persons into our own conduct" (Mead, 1934, p. 69). Because we are continually taking the attitudes of others toward our vocal gestures, these gestures become part of a "universe of 
discourse", which is for Mead a system of shared social meanings, "constituted by a group of individuals carrying on and participating in a common social process of experience and behavior, within which these gestures or symbols have the same or common meanings for all members of that group" (Mead, 1934, p. 89). Although Mead does not make the connection explicitly, we might think of this process of people continually taking on the attitudes of others toward their words as the mechanism for the emergence of the community-mind and the objectivity of language.

The universality of relationships between words and their meanings (i.e., a 'dog' is any dog, not just this dog before me now) suggests an arbitrary connection - that it doesn't matter which word is used for which meaning. But Mead argues that language "would never have arisen as a set of bare arbitrary terms which were attached to certain stimuli" (Mead, 1934, p. 189). This point harks back to the emergence of language from the use of gestural conduct to organize the social act. It also points to the embodiment of language and its meanings. Mead's favourite example of taking the attitude of the other is our tendency to ask someone to do something and immediately begin to do it ourselves: "You ask somebody to bring the visitor a chair. You arouse the tendency to get the chair in the other, but if he is slow to act you get the chair yourself" (Mead, 1934, p. 67). The meaning of what we say lies in this shared response. The meaning is embodied, but not invariable. If one were to look for the idea of a dog in the central nervous system, Mead argues, “one would find a whole group of responses...a possible playmate, a possible enemy, one's own property or somebody else's" (Mead, 1934, p. 71). Some of these responses are in all of us and others vary with individuals, but there is always an "organization of the responses which can be called out by the term 'dog'" (Mead, 1934, p. 71). The idea of a dog, then, is a set of possible responses to the word 'dog'. It is not so much that we share the meaning of the word. It is more that we share a set of possible embodied responses to hearing the word spoken. It is this set of possible meanings that forms the limit to the 'multiple meanings' of the word (Volosinov, 1973). The particular vocal gesture that calls out these responses is far from arbitrary; nor does it acquire its meaning from its position in a set of symbols. On the contrary, for Mead, relationships between words and their meanings are embedded in experience, or the history of responses called out by words. 


\section{Language and Mind}

As the focus of this paper is on the potential contribution of Mead's work to an ecological perspective on the psychology of language learning, it has dealt with his ideas on language in some detail. It will deal with his ideas on mind more briefly and in relation to Mead's view that mind emerges from language. MSS covers a number of psychological phenomena in what Mead takes to be their evolutionary sequence. However, everything that he has to say on the topic of mind -whether it is concerned with conscious thought, self-consciousness, the self, subjectivity or social control - tends to come back to language. He is especially clear on the point that language comes before mind. To take one example,

[T]here neither can be nor could have been any mind or thought without language; and the early stages of the development of language must have been prior to the development of mind or thought (Mead, 1934, p. 192).

It was also clear to Mead that, "the social act, in its more elementary stages or forms, is possible without, or apart from, some form of consciousness" (Mead, 1934, p. 18). All kinds of organisms engage in social behaviour. What distinguishes human social behaviour from the social behaviour of other organisms is the use of language, consciousness being an emergent from the use of language to organize the social process.

This is not to say that language and mind develop one after the other. Beyond a certain point in the evolution of the vocal gesture, language and mind develop in tandem; the more complex stages of mind depending on a greater complexity in language. For example, if the meaning of a word is a set of possible responses, ideas are responses that we do not carry out: "possibilities of overt responses which we test out implicitly in the central nervous system and then reject in favor of those which we do in fact act upon" (Mead, 1934, p. 99). Thinking is, essentially, " $[\mathrm{t}]$ he internalization in our experience of the external conversations of gestures which we carry on with other individuals in the social process" (Mead, 1934, p. 47). Abstract thinking emerges from more abstract conversations of gestures with the "generalized other": "abstract concepts are concepts stated in terms of the attitudes of the entire social group or community" (Mead, 1934, pp. 155-156 footnote). For Mead language is "essential for the development of the self” (Mead, 1934, p. 135). In order for the self to emerge, the individual must become an "object to himself", which can only result from "social intercourse in which one 
is addressing other persons and at the same time addressing one's self” (Mead, 1934, p. 142). "I know of no other form of behavior than the linguistic in which the individual is an object to himself," Mead writes, "and, so far as I can see, the individual is not a self in the reflexive sense unless he is an object to himself" (Mead, 1934, p. 142). This argument on the emergence of the self is typical of Mead's 'it could not have happened otherwise' style of reasoning. Yet, his comments are often more suggestive than conclusive. Mead often reminds us that everything to do with mind goes back to language, but his work lacks an account of the evolution of the higher forms of language to match his analysis of the evolution of the higher forms of mind. There is, however, a general assumption that language and mind somehow pull each other along the evolutionary scale. (De Laguna (1970), whose account of the origins of language and mind had much in common with Mead's, offers an interesting account of the development of language forms and structures along these lines). The key point to emerge from his work on mind, however, is the conceptual priority of language. This potentially has great significance for the way in which we conceptualize the psychology of language learning. Arguably the psychology of language learning should not be only a matter of what the psychology of the mind tells us about language learning, but also a matter of what our knowledge of language and language learning has to contribute to the psychology of mind.

\section{Environment}

Mead did not use the term ecology, but he did discuss the environment in in Mead (1925) and in several later sections of MSS. To recapitulate, Mead viewed the behaviour of an organism as the sum of its reactions to objects in the environment in which it lives. Behaviour is how the organism selects or adapts to the environment. The environment includes other organisms, among which those belonging to the same group hold a special place as "social objects" that the organism both reacts to and cooperates with. The organism's own body is also part of the environment, "a part of the set of environmental stimuli to which it responds or reacts" (Mead, 1934, p. 172). Mead tends to emphasize how language and mind emerge from social behaviour. However, his approach could well be described as ecological, in as much as behaviour is a matter of how organisms get to grips with both the social and material aspects of the environment. Two points stand out in his discussion of the environment as being especially relevant to an ecological 
view of language learning: the organism's part in determining its environment and the individuation of the environment.

The notion of the environment was already part of evolutionary thinking. However, Mead observed a tendency among writers who viewed evolution as environmental adaptation to think of "a pre-existent environment just there....and then to think of this environment affecting the form, setting the conditions under which the form can live" (Mead, 1934, p. 246). The problem is set up as one of an environment to which the organism adjusts. In contrast to this view, Mead emphasizes the part that the organism plays in the determination of its own environment, which is especially developed in humans due to the capacity for language and thought. In a basic sense, all organisms determine their environments through their 'sensitivity', as they can only react to objects that their sensitivity reveals. The significance of language and thought, therefore, is that they increase the diversity of human sensitivity and, consequently, increase both the possible responses to the environment and its size.

While many organisms adapt their environments to their needs (termites build nests, beavers build dams, and so on), the reciprocity between human beings and their environments is considerably enhanced by the human capacity for attention. For Mead, "[t]he human animal is an attentive animal and his attention may be given to stimuli that are relatively faint" (Mead, 1934, p. 25). Attention is both a selective process and an organizing process. It allows us to organize the field in which we act. And for Mead, attention is a distinctively human capacity, with which the human organism "goes out and determines what it is going to respond to, and organizes that world" (Mead, 1934, p. 25). Human beings also have a developed capacity to organize their environment in time.

There is an organized set of responses which first send off certain telegrams, then select the means of transportation, then send us to the bank to get money, and then see to it that we get something to read on the train. As we advance from one set of responses to another we find ourselves picking out the environment which answers to this next set of responses. (Mead, 1934, p. 128)

Mead's view, thus, provides support for an ecological view of language learning in which the learner's attention to environmental resources and consequent modification of the learning 
environment plays a key role. The part played by language in this determination of the spatial and temporal aspects of the environment will be discussed shortly.

In an article entitled 'The genesis of the self and social control', Mead (1925) also linked the capacity for attention to the individuation of the environment. The selective power of attention determines the environment and "the consciousness of the organism consists in the fact that his future conduct outlines and defines its objects" (Mead, 1925, p. 256). To the extent that the organization of this consciousness varies from individual to individual, each individual has a "private environment" (Mead, 1925, p. 256.). It is not clear whether Mead viewed consciousness and attention as characteristics of all living organisms. The passages from MSS cited above suggest that he probably did not. In any case, it is clear that he viewed consciousness and attention as being particularly developed in humans, to the point where they also determine relationships between the individual and the community. "[E]ach individual," he wrote, "has a world that differs in some degree from that of any other member of the same community.... [He] stratifies the common life in a different manner, and the life of the community is the sum of all these stratifications" (Mead, 1925, p. 260). Individuation of the environment is, moreover, both subjective (different perspectives on a shared environment) and objective (each individual actually has a different environment).

While attention plays the major role in Mead's account of the determination and individuation of the environment, language also plays its part. This goes back, in part, to the by now familiar principle that all phenomena of the mind depend on language. The sensitivity of the human organism enlarges the environment and attention "picks out" elements from it and brings them more directly into the social process. But it is language that "serves definitely to indicate just these elements and thus to bring them within the field of voluntary attention" (Mead, 1934, p. 95). More than this, however, Mead argues that "the social process, as involving communication, is in a sense responsible for the appearance of new objects in the field of experience" (Mead, 1934, p. 77). The organism's determination of the environment involves something more than the control of spatial and temporal aspects. It also brings new objects into the world. This is true of all organisms that modify their environments. When termites build a nest of clay, they bring a new object into the world. The human capacity for language accelerates this creation of new objects exponentially. "Symbolization constitutes objects not constituted before,” Mead writes, “objects which would not exist except for the context of social 
relationships wherein symbolization occurs" (Mead, 1934, p. 78). Mead's view, here, would seem to support a view of language learning as a creative process, in which linguistic interaction with environmental resources leads to the emergence of new language in the learner and the modification of the environment itself.

\section{Language Learning}

Mead had a lot to say about language, but little to say about language learning. What he did say hints at the potential for the application of his ideas. Discussing the question of "whether anything novel can appear", Mead answers with the concept of "emergence", which "involves a reorganization, but the reorganization brings in something that was not there before" (Mead, 1934, p. 198). To exemplify the concept, he uses the familiar example of water appearing when hydrogen and oxygen come together. A second example is a group of individuals who work together and use a common language:

The common language is there, but a different use of it is made in every new contact between persons; the element of novelty in the reconstruction takes place through the reaction of the individuals to the group to which they belong. That reconstruction is no more given in advance than is the particular hypothesis which the scientist brings forward given in the statement of the problem. (Mead, 1934, p. 198)

The idea that new language emerges from language use in the context of social activity is a relatively new one for the psychology of language learning. And although Mead is concerned with the emergence of something novel in language, there can be no doubt that learning is involved. He also has little to say about learning, but elsewhere he writes that the direction of attention "is the way in which we break up complex activities and thereby make learning possible" (Mead, 1934, p. 95). What takes place is "an analysis of the process" and "a reconstruction of the act" (Mead, 1934, p. 95). Learning is, in effect, analyzing and recombining to make something new. This suggests and approach to second language learning, in which we see second knowledge not simply as the expression of thought that are already present in the first language, but as the emergence of an essentially new knowledge tied to new language.

In a passage toward the end of $M S S$, in which Mead turns, somewhat unexpectedly, to additional language learning, he writes: 
A person learns a new language and, as we say, gets a new soul. He puts himself into the attitude of those that make use of that language. He cannot read its literature, cannot converse with those that belong to that community, without taking on its peculiar attitudes. He becomes in that sense a different individual. (Mead, 1934, p. 283).

The idea that additional language learning is matter of developing a new identity is also relatively new to the psychology of language learning. For Mead, this appears to flow quite naturally from the idea of taking on the attitude of the other. Again, his view supports an approach in which language learning is seen as a creative process in which the emergence language leads to new ways of thinking about self and others.

\section{Conclusion}

In writing this article, I do not want to suggest that Mead has a fully formed ecological theory with the potential to transform our understanding of language learning. My aim is more

limited: to suggest that his work is worth reading for the insights it may offer an environmental view of language learning. In thus limiting my claim for Mead's relevance, I am aware of a number of problems in interpreting his work.

Mead's work is no more difficult than that of any other writer of his time, but the reader is left with the task of stitching together a coherent account of his ideas from various sources. Beginning with Morris's work in compiling MSS, much Mead scholarship has been concerned with making sense of a body of work that lack's the coherence that its interpreters attach to it. My account is also an interpretation of Mead's work that may be influenced by a desire to find more coherence and contemporary relevance in it than is actually present in the text. In one sense, this lack of coherence adds interest to Mead's body of work. It remains a terrain to be explored. In addition, Mead's positions on the origins and evolution of language are largely conjectural and come from a field of inquiry that many linguists of the time had abandoned for want of empirical evidence.

Mead is also much more confident in his assertions on the origins of language and mind, than he is on relationships between the higher forms of language and mental activity. His work is also marked by an implicit belief in a hierarchy of life forms that places the uniquely human capacities for language and self-conscious thought at the pinnacle of evolutionary development 
(although his view of the importance of sociality and gesture to human evolution remains plausible in view of more recent work, e.g. Deacon, 1997; Gamble, Gowlett \& Dunbar, 2014). When Mead writes, toward the end of MSS, that "human society has reached an end which no other form has reached, that of actually determining, within certain limits, what its inorganic environment will be" (Mead, 1934, p. 252), he seems almost blissfully unaware of the potentially disastrous consequences of this achievement for the future of organic life as we know it. Lastly, there is the much broader question, which I will leave open, of whether the ideas of a thinker who wrote almost a century ago could have any real relevance to our current understanding of the psychology of language and language learning.

I believe that Mead is worth reading for two main reasons. First, we are accustomed to think of the psychology of language learning as a social psychology. It is now almost axiomatic that language is a social product (for some, a process) and that language learning is a social process. But what is it about language, exactly, that makes language learning a social process? Mead's account of the origins and development of language is thoroughly social and, if we were to accept this account, it would make a great deal of sense to situate language learning within the development of language itself. Language develops as people learn language, and vice versa. The importance of embodiment in Mead's account of language and meaning suggests that learning the language(s) of a community in which one is born and raised is a very different matter to learning a second language later in life. There is, nevertheless, a hint of continuity in the suggestion that second language learning, like first language(s) learning, involves "taking on the attitude of the other": perhaps the attitude of others within a new community, or perhaps, the attitudes of the other community as a social object. The idea that taking on the attitude of the other may be the fundamental social mechanism of language learning is, I would argue, worth exploring, not least because it now has a potential neuroscience correlate in the idea of 'mirror neurons', which fire both when we perform an action (e.g., produce an utterance) and when we observe it (e.g., hear an utterance) (Iacoboni, 2008).

The more important contribution of Mead's work, however, may be its contribution to a clearer understanding of social interaction in the environment. Arguably, by starting from social relationships, the ecological perspective has tended to pick out verbal interaction from its wider environmental contexts. From Mead's perspective, however, verbal interaction cannot be construed simply as interaction among people. Mead's environment is an environment of objects 
in which social objects (other people) have a special place. But social interaction always engages other objects in a wider environment. Mead's colleague Dewey (1925: 179) makes this point even more strongly when he argues that meaning arises in cooperative behaviour in which the "response to another's act involves contemporaneous response to $a$ thing as entering into the other's behaviour"; that in attributing meaning to a speaker's intent, "we take for granted another person who is to share in the execution of the intent, and also something, independent of the persons concerned, through which the intent is to be realised" (my italics). The point of departure that Mead offers to an ecological perspective on the psychology of language learning, therefore, is one that situates the language learning mind in an 'environmental' context that is larger than the 'social context' of verbal interaction. A focus on the external environment might seem to move us away from the psychology of language learning. Paradoxically, however, Mead's work seems to offer a way into the psychology of language learning from the direction of human interactions with the environment in which the emergence of language plays a crucial part in the emergence of mind.

\section{References}

Blumer, H. (1966). Sociological implications of the thought of G. H. Mead. American Journal of Sociology, 71(5), 535-544. doi:10.1086/224171

Blumer, H. (1980). Mead and Blumer: The convergent methodological perspectives of social behaviorism and symbolic interactionism. American Sociological Review, 45(3), 409-419. doi:10.2307/2095174

Bronfenbrenner, U. (1979). The ecology of human development: Experiments by nature and design. Cambridge, MA: Harvard University Press.

Chomsky N. (1959). Review of Skinner's verbal behavior. Language, 35(1), 26-58. doi:10.2307/411334

Darwin, C. (1872). The expression of the emotions in man and animals. London, UK: John Murray.

Da Silva, F. C., \& Vieira, M. B. (2011). Books and canon building in sociology: The case of mind, Self, and Society. Journal of Classical Sociology, 11(4), 356-377. doi:10.1177/1468795x11415148

De Laguna, G. A. (1970). Speech: Its function and development. College Park, MD: McGrath Publishing Company. (First published in 1927 by Yale University Press).

Deacon, T. (1997). The symbolic species: The co-evolution of language and the brain. New York, NY: W. W. Norton. 
Dewey, J. (1925). Experience and nature. New York, NY: W. W. Norton.

Franks, D. D. (2013). Why we need neurosociology as well as social neuroscience: Or - why role-taking and theory of mind are different concepts. In D. D. Franks and J. H. Turner (Eds.), Handbook of neurosociology (pp. 27-32). Dordrecht, Germany: Springer.

Gamble, C., Gowlett, J., \& Dunbar, R. (2014). Thinking big: How the evolution of social life shaped the human mind. London, UK: Thames \& Hudson.

Habermas, J. (1981). The theory of communicative action: Volume 2. Lifeworld and system: A critique of functionalist reason. Cambridge, UK: Polity.

Huebner, D. R. (2012). The construction of Mind, self, and society: The social process behind G. H. Mead's social psychology. Journal of the History of the Behavioral Sciences, 48(2), 134-153. doi:10.1002/jhbs.21544

Iacoboni, M. (2008). Mirroring people: The science of empathy and how we connect with others. New York, NY: Picador.

Kramsch, C. (Ed.) (2002). Language acquisition and language socialization: Ecological perspectives. London, UK: Continuum.

Kramsch, C. (2008). Ecological perspectives on foreign language education. Language Teaching, 41(3), 389-408. doi:10.1017/s0261444808005065

Leather, J. (2002). Modeling the acquisition of speech in a 'multilingual' society: An ecological approach. In C. Kramsch (Ed.), Language acquisition and language socialization: Ecological perspectives (pp. 47-67). London, UK: Continuum.

Lemke, J. L. (2002). Language development and identity: multiple timescales in the social ecology of learning. In C. Kramsch (Ed.), Language acquisition and language socialization: Ecological perspectives (pp. 68-87). London, UK: Continuum.

Madzia, R. (2013). Mead and self-embodiment: Imitation, simulation, and the problem of taking the attitude of the other. Österreich Z. Soziol, 38(SI), 195-213. doi:10.1007/s11614-0130104-4

Malinowski, B. (1923). Supplementary essay. In C. K. Ogden \& I. A. Richards, The meaning of meaning: A study of the influence of language upon thought and the science of symbolism. (pp. 296-336). New York, NY: Harcourt, Brace \& Co.

Mead, G. H. (1904). The relations of psychology and philology. Psychological Bulletin, 1(11), 375-391. doi:10.1037/h0073848

Mead, G. H. (1910). What social objects must psychology presuppose? Journal of Philosophy, 7(7), 174-180. doi:10.2307/2010782

Mead, G. H. (1922). A behavioristic account of the significant symbol. The Journal of Philosophy, 19(6), 157-163. doi:10.2307/2939827

Mead, G. H. (1925). The genesis of the self and social control. International Journal of Ethics, 
35(3), 251-277. doi:10.1086/intejethi.35.3.2377274

Mead, G. H. (1934). Mind, self, and society from the standpoint of a social behaviourist. Chicago, IL: University of Chicago Press.

Mercer, S. (2016). The contexts within me: L2 self as a complex dynamic system. In J. King (Ed.), The dynamic interplay between context and the language learner (pp. 11-28). Basingstoke, UK: Palgrave Macmillan.

Morris, C. W. (1934). George H. Mead as social psychologist and social philosopher. Introduction to G. H. Mead, Mind, self, and society from the standpoint of a social behaviorist (pp. ix-xxv). Chicago, IL: University of Chicago Press.

Peirce, C. S. (1992/1998). Selected philosophical writings, Vols. 1 and 2. Bloomington, IN: Indiana University Press.

Saussure, D. de (1983). Course in general linguistics. Trans. R. Harris. London, UK: Duckworth.

Shook, J. R. (2013). Social cognition and the problem of other minds. In D. D. Franks and J.H. Turner (Eds.), Handbook of neurosociology (pp. 33-46). Dordrecht, Germany: Springer.

Tallerman, M., \& Gibson, K. R. (Eds.) (2012). The Oxford handbook of language evolution. Oxford, UK: Oxford University Press.

Tudor, I. (2003). Learning to live with complexity: towards an ecological perspective on language teaching. System, 31(1) 1-12. doi:10.1016/s0346-251x(02)00070-2

van Lier, L. (2002). An ecological-semiotic perspective on language and linguistics. In C. Kramsch (Ed.), Language acquisition and language socialization: Ecological perspectives (pp. 140-64). London, UK: Continuum.

van Lier, L. (2004). The ecology and semiotics of language learning: A sociocultural perspective. Boston, MA: Kluwer Academic Publishers.

Volosinov, V. N. (1973). Marxism and the philosophy of language. Trans. L. Matejka \& I. R. Titunik. New York, NY: Seminar Press.

Vygotsky, L. S. (1978). Mind in society. Cambridge, MA: Cambridge University Press.

Vygotsky, L. S. (1986). Thought and language. Cambridge, MA: MIT Press.

Watson, J. B. (1914) Behavior: An introduction to comparative psychology. New York, NY: Henry Holt. 